\title{
Figure S4A
}

\section{PpY-55A}

\section{Inversion 1 Inversion 2}

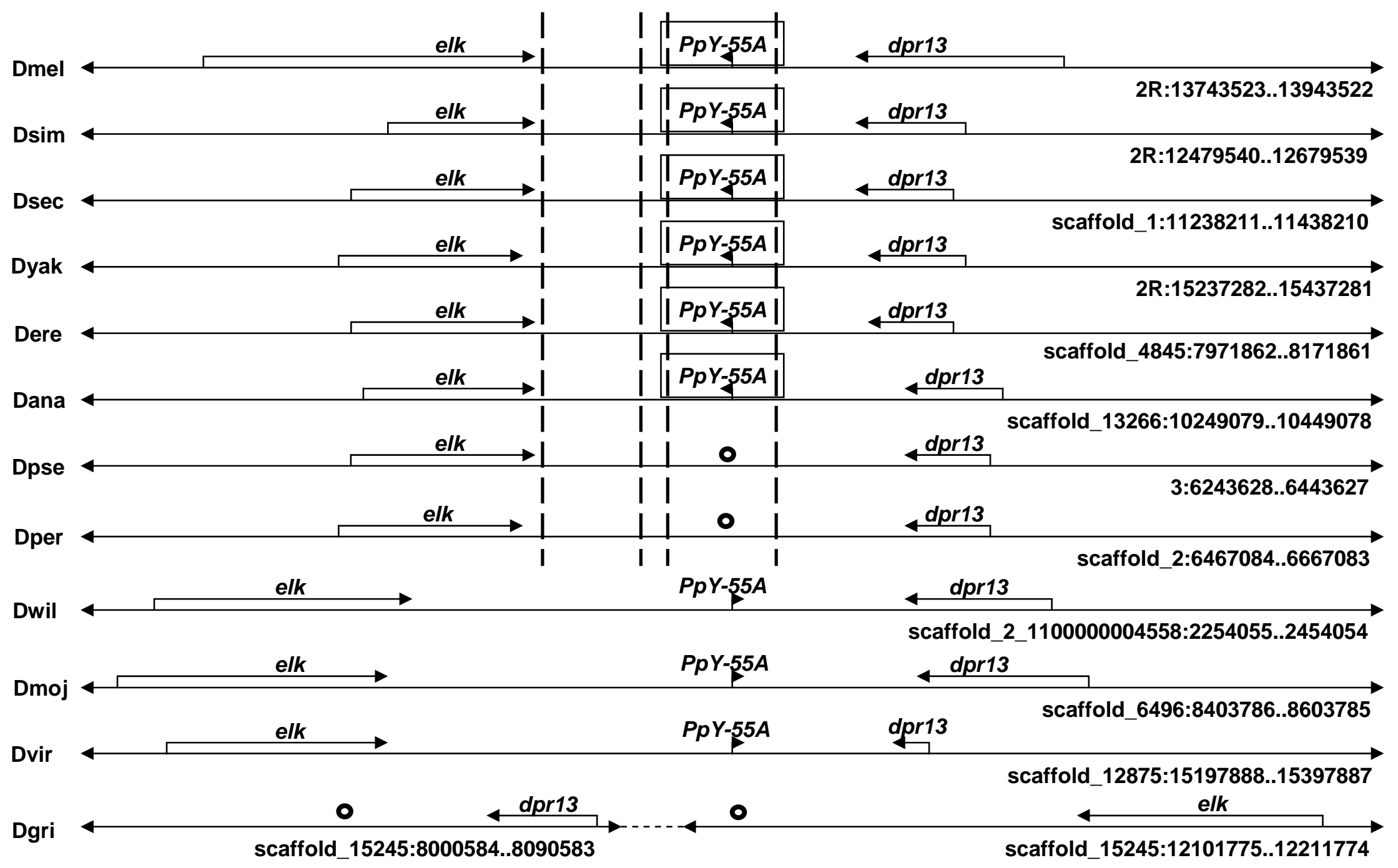




\section{Figure S4B}

\section{PpY-55A}

Inversion 1 Inversion 2

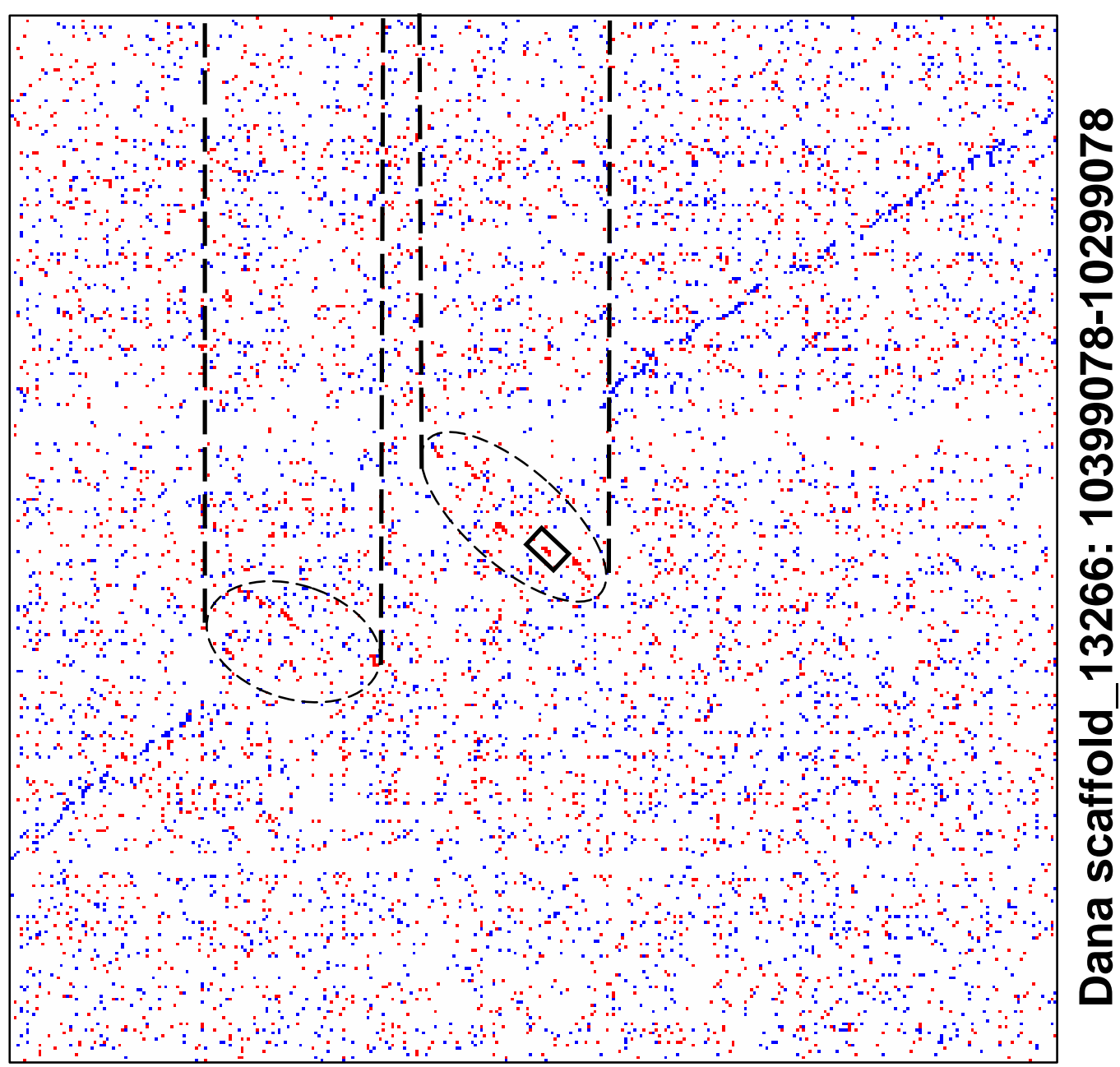

Dwil scaffold_2: 2304055-2404055 


\section{PpD5+}

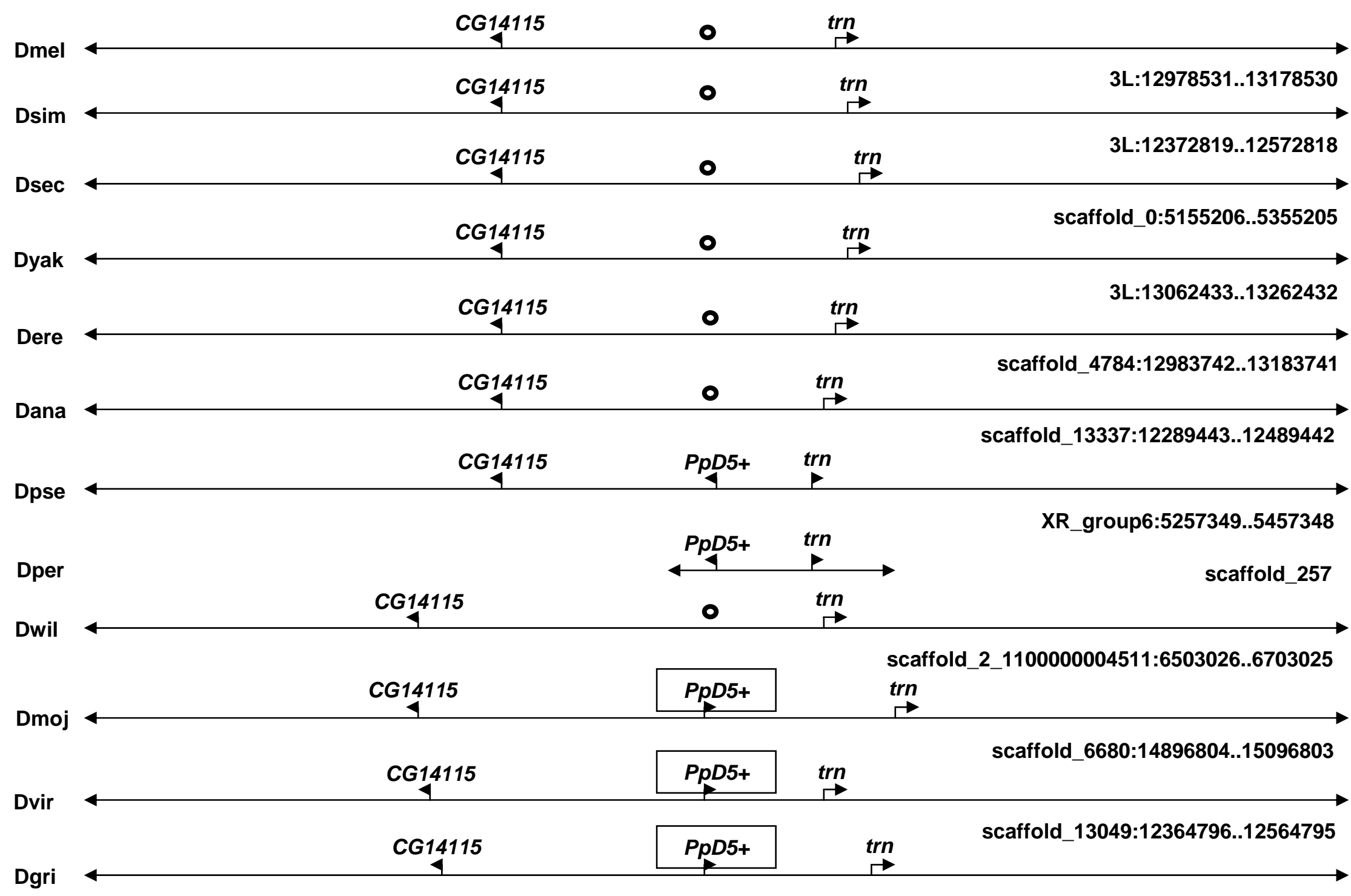

scaffold_15110:22966288..23166287 


\section{Figure S4D}

\section{PpD5+}

Deletion
Inversion

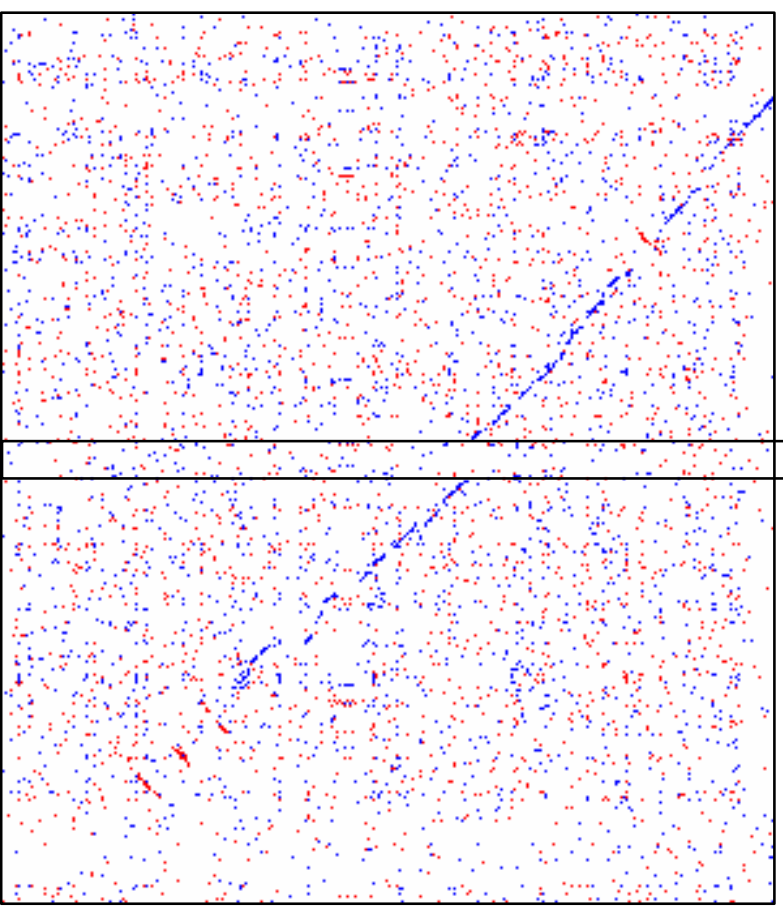

Dana scaffold_13337: 12364442-12409442

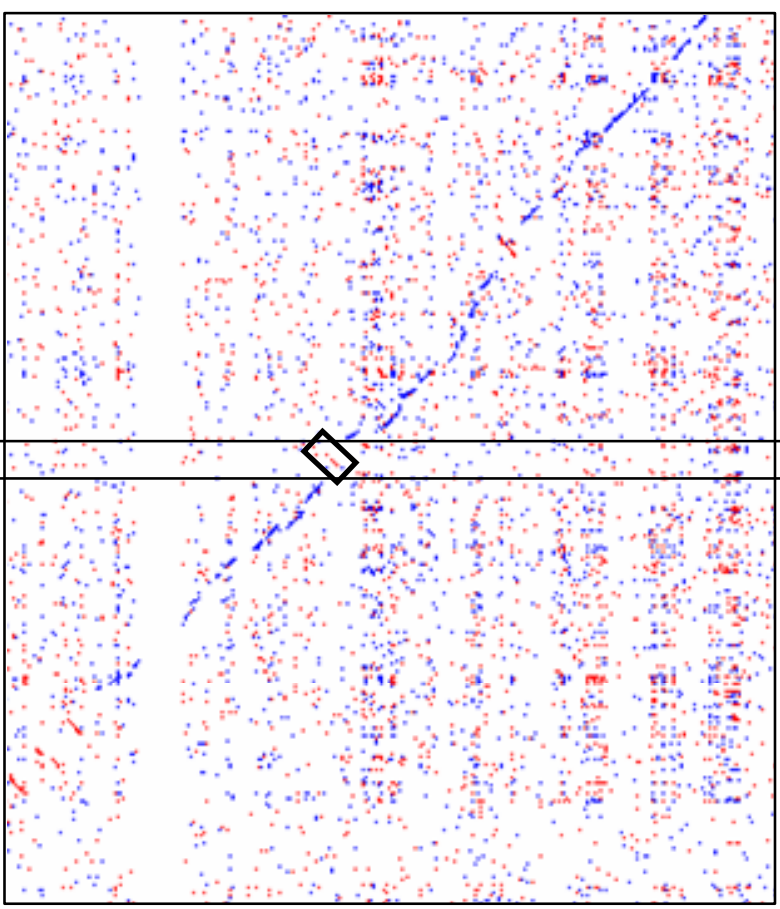

Dpse scaffold_XR_group6: 5337349-5382349
Deletion

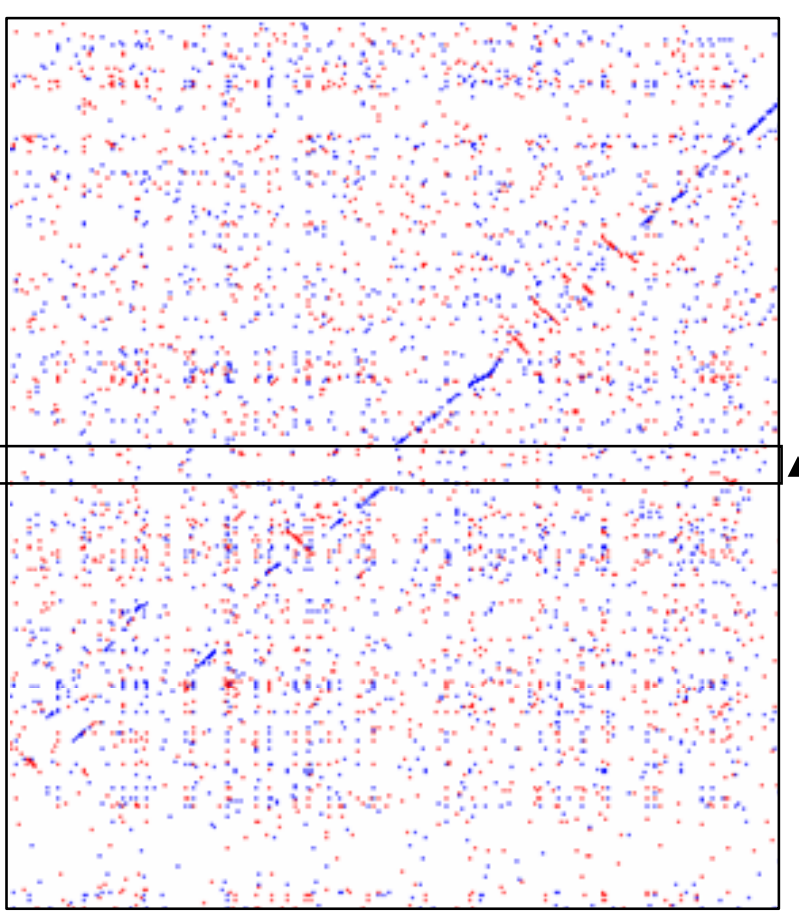

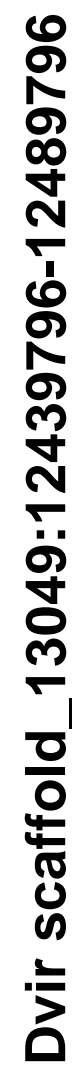

Dwil scaffold_2_1100000004511: 6558026-6603026 


\section{Figure S4E}

\section{Location 1}

\section{PpD5}

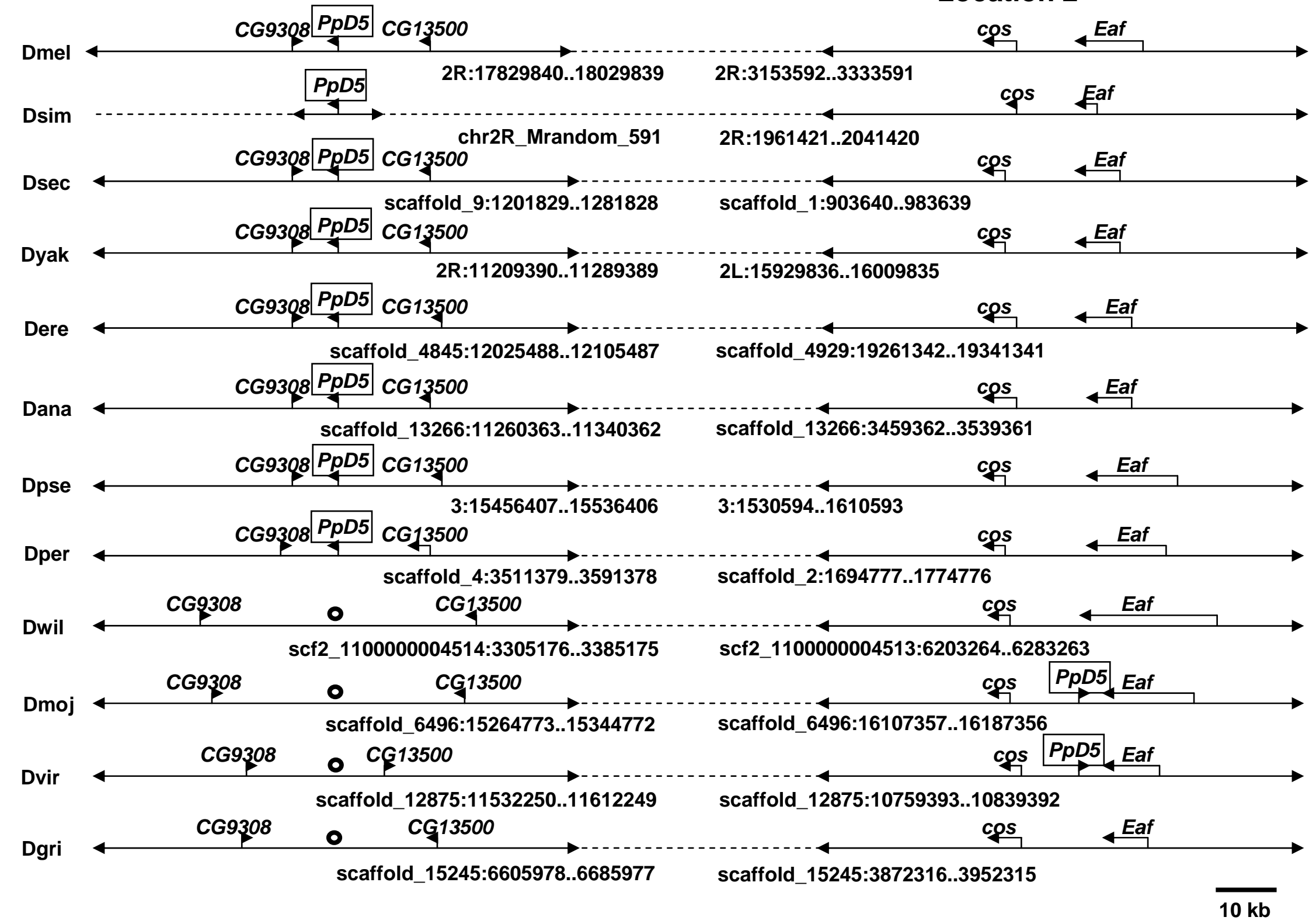

\section{Location 2}




\section{Figure S4F}

\section{PpD5}

Gene Degradation in Location 1

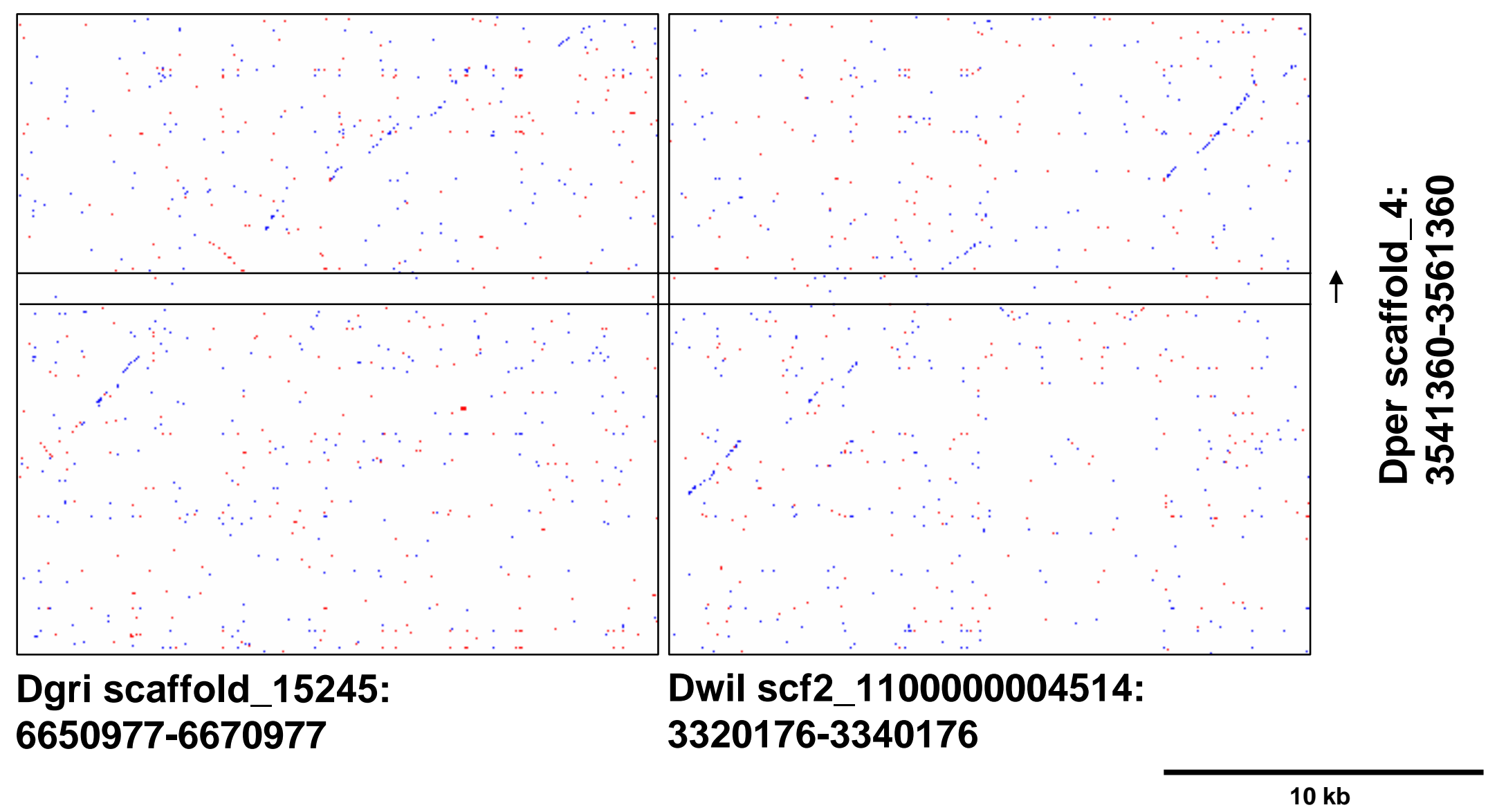




\section{Figure S4G}

\section{PpD5}

Gene Insertion in Location 2

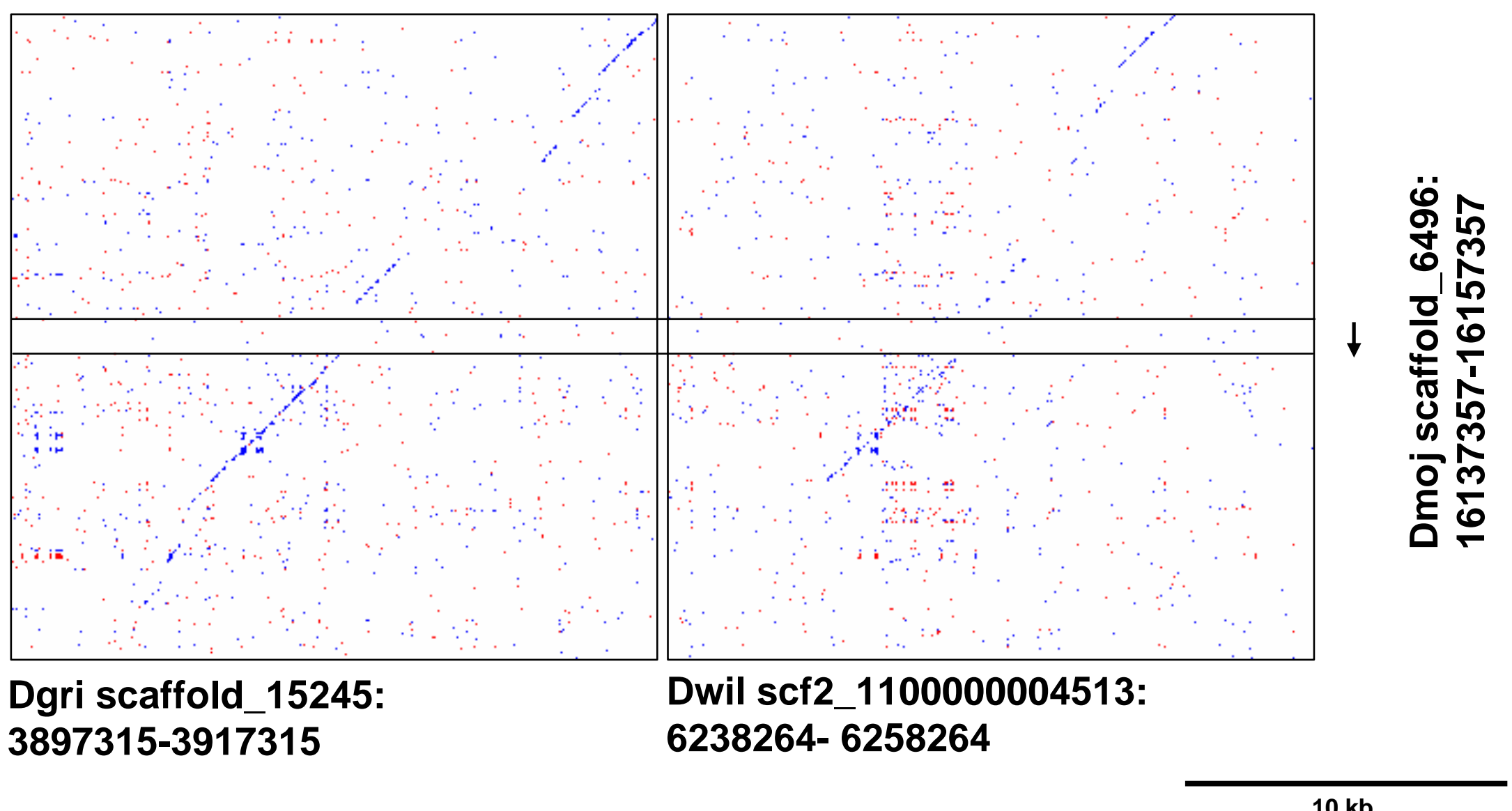

